\title{
Pedagogia do oprimido, o manuscrito: do contexto histórico às tramas da obra
}

\author{
Pedagogy of the oppressed, the manuscript: from the historical context to \\ the plots of the work
}

Nadia Conceição Lauriti Doutora em Educação Universidade Nove de Julho - Uninove. São Paulo, SP - Brasil. nadia@uni9.pro.br

Ligia de Carvalho Abões Vercelli Doutora em Educação Universidade Nove de Julho - Uninove. São Paulo, SP - Brasil. ligia@uni9.pro.br

Resumo: Este artigo, excerto da tese de doutoramento de uma das autoras, propõe-se a discutir o princípio da dialogicidade enquanto vetor de pensamento freiriano a partir da contextualização histórica da publicação fac-similada do manuscrito da Pedagogia do Oprimido. Recupera-se o contexto histórico em que a obra foi gestada no Chile, entre 1967 e 1968 , descrevendo o itinerário percorrido até a primeira publicação em 2013. Trata-se de uma pesquisa qualitativa de natureza teórico-analítica fundamentada em aportes oriundos prioritariamente da análise do discurso e da crítica genética. Verificou-se, no manuscrito, o embrião matricial do que se poderia denominar Pedagogia do diálogo educomunicativo, urdida com o oprimido e não para o oprimido. Conclui-se que o manuscrito abre novas possibilidades para o leitor do século XXI, tanto para a apropriação de novos sentidos para a obra quanto para sua validação histórica.

Palavras chave: manuscrito; pedagogia do oprimido; dialogicidade; Paulo Freire.

Abstract: This article, excerpt from the doctoral thesis of one of the authors,

aims to discuss the principle of dialogicity as a vector of Freirian thought from the historical context of the fac-similada publication of the manuscript of the Pedagogy of the Oppressed. The historical context in which the work was created in Chile between 1967 and 1968 is recovered, describing the itinerary followed until the first publication in 2013. It is a qualitative research of theoreticalanalytical nature based on contributions coming primarily from discourse analysis and genetic criticism. In the manuscript, the matrix embryo of what could be called the Pedagogy of the Educommunicative Dialogue was found, woven with the oppressed and not for the oppressed. It can be concluded that the manuscript opens new possibilities for the 21 st century reader, both for the appropriation of new meanings for the work and for its historical validation.

Key-words: manuscript; pedagogy of the oppressed; dialogic; Paulo Freire.

Cite como

(ABNT NBR 6023:2018)

LAURITI, Nadia Conceição; VERCELLI, Ligia de Carvalho Abões. Pedagogia do oprimido, o manuscrito: do contexto histórico às tramas da obra. Dialogia, São Paulo, n. 39, p. 1-17, e20738, set./dez. 2021. Disponível em: https://doi.org/10.5585/39.2021.20738.

American Psychological Association (APA)

Lauriti, N. C., \& Vercelli, L. de. C. A. (2021, set./dez.) Pedagogia do oprimido, o manuscrito: do contexto histórico às tramas da obra. Dialogia, São Paulo, 39, p. 1-17, e20738. https://doi.org/10.5585/39.2021.20738. 


\section{Introdução}

No trabalho de mobilização da memória, o historiador recolhe osartefatos do passado, como aquele que "escova a história a contrapelo" (BENJAMIN, 1994, p. 431).

Um leitor não sai do diálogo com a palavra expressa na obra de Paulo Freire sem ser atravessado pela pluralidade de significações que ela possibilita, sem se apoderar dessa palavra dialógica, sem comprometer-se com a pronúncia do mundo que ela inspira e, principalmente, sem saborear a poeticidade das entrelinhas de seus ensaios que contemplam massas imensas e ilimitadas de sentidos que sobrevivem através do tempo, sempre de forma renovada.

É no escopo dessa festa de renovação de olhares e de sentidos que se insere este artigo sobre a publicação fac-similada do manuscrito de Pedagogia do Oprimido. Trata-se de uma obra com canonicidade implícita. O texto vertebrador do pensamento freiriano e seu estudo poderá contribuir para confirmar a organicidade conceitual que perpassa todos os seus livros, modulada pelo princípio da dialogicidade.

Entende-se que o leitor, diante do manuscrito, tem a possibilidade de dialogar com um documento não apenas de caráter histórico, mas também de natureza discursiva e poética, cujo acesso para a comunidade leitora, estudiosos e pesquisadores só se tornou possível em 2013, no contexto das comemorações do cinquentenário da experiência de Paulo Freire em Angicos, pela mobilização de Mafra, Romão e Gadotti, que contextualizam, na apresentação que introduz o texto, a trajetória da obra, de sua gênese até sua publicação.

As condições histórico-sociais da época da sua produção, entre 1967 e 1968, e da circulação posterior - que certamente interferirão nas esferas de recepção da obra pelo leitor de hoje, dado seu caráter documental - foram minuciosamente recuperadas pelos organizadores da publicação, revelando-se o diálogo com o passado em que surgiu a obra, que não é visto apenas como um momento anterior ao presente, mas como sua fonte conceitual e expressiva.

Na obra Pedagogia do Oprimido: (o manuscrito), a dialogicidade, entendida por Freire (2013, p. 88) como um "[...] fenômeno humano, uma exigência existencial, um trabalho que se faz na açãoreflexão [...]", [rever esta citação, cf. com original] pode ser considerada como o princípio de maior força operacional do seu pensamento. Está presente em todas as suas obras e se encontra visivelmente expressa também no manuscrito, revelando a mão que escreve, que hesita, que se auto-corrige, que rasura, que escolhe, que substitui ou acrescenta palavras e que recria no texto a experiência vivida por ele, comprovando a tese de Bakhtin (1997, p. 95) de que “[...] a palavra está sempre carregada de um conteúdo ou de um sentido ideológico ou vivencial”. 
Paulo Freire estabelece, assim, uma relação dialógica não só com o outro, com as obras anteriores ou com o mundo, mas também e, sobretudo, com a linguagem, como ato de sua escritura. Verdadeira releitura do mundo que se faz presente na revisão de sua própria palavra, levando-o à reescrita do lido, como forma de refazer continuamente seu ato cognoscente. Linguagem e realidade entrelaçam-se, assim, dinamicamente e revelam a natureza de um pensamento transindividual, que não renuncia ao que de histórico existe no discurso, incluindo o homem no discurso e o discurso no ser. Dialogam, no mesmo espaço-tempo da escritura do manuscrito, escritor, autor, leitor e revisor, que desconfiam da palavra e, por essa razão, monitoram-na e controlam a qualidade do conteúdo e da forma. Roland Barthes (1987, p. 43) corrobora com esse entendimento, quando afirma que

Transformar o mundo é também transformar sua linguagem, combater sua esclerose e resistir aos seus acomodamentos; é livrá-la de estereótipos, de chavões, do lugar comum. Nos estereótipos sob o manto da naturalidade, a ideologia é veiculada à inconsciência dos seres falantes em relação às suas condições de fala. É necessário ouvir a própria fala e desconfiar da palavra para melhor entendê-la.

É por essa relação com a palavramundo, isto é, com os componentes e valores da realidade e da vida que são veiculados pela palavra, que o estilo personalíssimo da escrita freiriana vai sendo tecido, desvelando sua forma de ser na linguagem. Por ser social, histórica e cultural, sua palavra deixa entrever a singularidade do seu ethos, sempre afetado e impregnado por essas relações. Sua marca autoral transcende a dimensão linguística no manuscrito e produz ressonâncias que podem ser apreendidas também no campo do discurso, revelando o modo como sua dialogicidade se materializa.

Essa dialogicidade é, assim, entendida como um princípio geral do seu agir na vida e no discurso. É o grande constructo que nasce de diálogos retrospectivos e prospectivos com sua própria escritura, com a cultura e com a realidade do mundo. Ele busca sempre o vir-a-ser do homem e do sentido do discurso, o eterno movimento da consciência criadora de novas realidades que, para formar-se e manifestar-se, precisa estar imersa na realidade.

\section{O manuscrito: contexto histórico}

Ler a publicação editorial fac-similada do manuscrito de Pedagogia do Oprimido, de 2013, é ter a possibilidade de "escovar a história a contrapelo", como nos lembra Walter Benjamin (1994). É ampliar o seu significado pelo resgate das marcas textuais "escovadas" e "escavadas" do passado, 
que se expõem para uma revisitação e permitem a apropriação de novos sentidos para uma obra inerentemente palimpsestuosa ${ }^{1}$.

Esse aspecto é fortalecido por importantes elementos paratextuais que contextualizam historicamente a trajetória da obra, como: a apresentação escrita por Mafra, Romão e Gadotti, responsáveis também pelo projeto editorial, organização e revisão da obra; uma entrevista com Jacques Chonchol, que esteve em posse do manuscrito por mais de 30 anos, e uma carta escrita por Paulo Freire, quando, em 1968, entregou o original da obra aos amigos Jacques Chonchol e sua esposa Maria Edy.

Em Alfabetizar e conscientizar: Paulo Freire, 50 anos de Angicos, Gadotti (2014) expõe uma detalhada cronologia da trajetória de Paulo Freire, contextualizando historicamente o tempoespaço em que Pedagogia do Oprimido foi escrito. Conta o autor que, logo após o Golpe de Estado, em $1^{\circ}$ de abril de 1964, o Programa Nacional de Alfabetização criado por Paulo Freire, baseado na experiência de Angicos, expandia-se vertiginosamente e consagrava o Sistema Paulo Freire para alfabetização em tempo rápido, mas foi extinto por ter sido considerado subversivo. Em 16 de junho, seu idealizador foi preso e permaneceu setenta e dois dias em uma cadeia do quartel de Olinda, até que, em setembro, foi exilado e, depois de uma breve passagem pela Bolívia, por não se adaptar à altitude do país, foi para o Chile, onde permaneceu até 1969. Ele só retorna ao Brasil em 1979, depois de lecionar na Universidade de Harvard (1969); de trabalhar no Conselho Mundial de Igrejas na Suíça (1970); de fundar, com outros exilados, o Instituto de Ação Cultural (IDAC) e dedicar-se ao trabalho com educação em países africanos (1971); e de atuar com essa equipe em programas de alfabetização da Guiné-Bissau, Cabo Verde, Angola e São Tomé e Príncipe (1975-1979).

Considerando-se a inseparabilidade do tempo cronos e do espaço topos, enquanto categorias históricas, e a sua importância na apreensão do sentido do mundo, Paulo Freire, apartado de sua terra e de sua gente por 16 anos, foi exilado não só de um lugar, mas também de um tempo; entretanto, não conseguiram exilá-lo da história e do futuro, já que foi declarado Patrono da Educação Brasileira, pela Lei ${ }^{\circ}$ 12.612, de 13 de abril de 2012, o que o instalou, merecidamente, na grande temporalidade que é o patamar no qual penetram apenas autores de obras universais, que se tornam referência para diferentes gerações.

O exílio e o encontro dialógico com essas diversas culturas com as quais conviveu possibilitaramlhe enveredar por profundidades novas de leituras sobre o mundo, já que esses novos sentidos se revelaram ao encontrar e sentir o significado das culturas dos lugares onde viveu e trabalhou.

${ }^{1}$ Utilizamos aqui a metáfora do palimpsesto para designar o manuscrito como um texto primitivo que foirasurado, dando lugar a outro. 
$\mathrm{Na}$ apresentação da obra, os organizadores Jason Ferreira Mafra, José Eustáquio Romão e Moacir Gadotti recuperam a história do manuscrito, confessando: "Há muito vínhamos acalentando o sonho de localizar e publicar, em fac-simile, os originais dessa obra, sabendo que os manuscritos estavam em poder de Jacques Chonchol e de Maria Edy em Santiago do Chile" (MAFRA; ROMÃO; GADOTTI, 2013, p. 4). Ele era o vice-presidente do Instituto de Desarrollo Agropecuario (INDAP) do Ministério da Agricultura do Governo Eduardo Frei Montalva (19641970) e Ministro da Agricultura do Governo de Salvador Allende (1970-1973), e ela, Maria de Oliveira Ferreira Chonchol, uma brasileira nascida em São Paulo, na cidade de Olímpia.

Com o golpe militar que derrubou o presidente Salvador Allende, Chonchol se exilou na Venezuela e depois na França por mais de vinte anos. Em entrevista concedida a José Eustáquio Romão, em agosto de 2013, que também se constitui como importante paratexto da obra, o próprio Chonchol relata, ao receber o manuscrito de Paulo Freire:

\footnotetext{
Algumas vezes cheguei a pensar que não fazia sentido ficar com ele. Pensei em doar o manuscrito à UNESCO. Ainda bem que não o fiz, porque me parece mais adequado que ele fique no Brasil, na terra de Paulo Freire, à disposição da humanidade. (CHONCHOL, 2013, p. 10).
}

Mesmo tendo sido sua biblioteca confiscada, os manuscritos foram preservados. Estavam reunidos em uma pasta, sob a forma de duzentas folhas soltas de papel almaço branco sem pauta e escritas com uma caneta-tinteiro. Eles não foram levados, por desconhecerem a importância do material e anos depois foram enviados pela mãe de Chonchol, por intermédio da filha, para a França e guardados por todos esses anos.

Paulo Freire morreu sem ter concretizado o desejo de rever os manuscritos, entretanto "tempus optimus index rerum omnium". As fronteiras entre presente, passado e futuro são flexíveis. Lida-se com um número plural de temporalidades e, para que o passado seja útil, ele deve delinear o futuro como enredo do presente. Foi exatamente o que ocorreu: o sonho não presenciado em vida por Paulo Freire foi realizado por seus amigos e seguidores, em 2013, em uma cerimônia especial.

Essa cerimônia encerrava o IV Seminário Internacional, realizado entre os dias 5 e 7 de novembro de 2013, na Universidade Nove de Julho (Uninove), que teve como tema Paulo Freire e a Educação Superior. O evento reuniu pesquisadores freirianos do mundo todo. Terminada a conferência A reforma agrária no Chile e a educação dos camponeses, Lutgardes Freire recebeu os originais da obra das mãos de Jacques Chonchol.

2 Tradução própria do latim: "O tempo é ótimo juiz para todas as coisas". 
Em entrevista concedida à Camilla Campos para a British Broadcasting Corporation (BBC) do Brasil, em 24 de julho de 2015, José Eustáquio Romão, historiador e amigo de Paulo Freire, revela aspectos importantes das tramas históricas que envolveram a volta do manuscrito para o Brasil. Relata que foi uma busca adiada por quinze anos e que Paulo Freire expunha aos amigos mais próximos a vontade de rever os manuscritos antes de morrer. O que se sabia, entretanto, à época, era apenas que os originais haviam sido datilografados. Desconheciam a existência de cópias manuscritas.

Paulo era muito desorganizado. Ele escrevia até em guardanapo quando tinha uma boa
ideia. Então um de seus amigos juntou essa papelada e datilografou em 1968. Quando
Paulo falava de manuscrito, eu achava que ele estava delirando. Mas não estava.
(ROMÃO, 2015, n.p).

Soube-se mais tarde que, em 1969, quando foi convidado a dar aulas em Harvard, antes de viajar, decidiu copiar seu livro e dar esse manuscrito de presente ao casal Chonchol. Localizado esse original, José Eustáquio Romão (2015, n.p) expõe que

A família dele (de Paulo Freire) nos autorizou a fazer mil exemplares do texto, mas não a vendê-los. Estamos distribuindo uma versão digitalizada a editores e às grandes bibliotecas do mundo, para que as novas edições se baseiem nisso aqui.

Nesta mesma entrevista, José Eustáquio Romão destaca, como principal diferença entre o manuscrito e a obra que se conhece hoje, a retirada dos diagramas em que Paulo Freire explica a Teoria da Ação Revolucionária em oposição à Teoria da Ação Repressora.

A este respeito, esclarece o autor:

A parte do livro em que Paulo Freire fala sobre a 'teoria da ação revolucionária' não existe em nenhuma edição em nenhuma parte do mundo. O que nos faz supor que os (editores) americanos tiraram diversas partes - eu já fiz uma leitura comparada e comprovei que não estão lá. Eles tiraram coisas que acharam um pouco mais perigosas para a ideologia liberal norte-americana. Não fazem por mal, mas por princípio ideológico. (ROMÃO, 2015 , n.p).

Em que pese a intencionalidade da excisão desse diagrama pela edição americana traduzida de Pedagogia do Oprimido, o distanciamento do contexto geográfico, político e cultural de produção da obra pode ter determinado esse viés ideológico. Traduções nunca estão isentas de intenções de natureza histórica, econômica e ideológica. Para essa direção apontam os estudos de Linda Hutcheon (2011, p. 9), professora de Literatura Comparada da Universidade de Toronto, que considera a tradução como uma forma de transcodificação de um sistema de comunicação para outro, alegando que "[...] a tradução inevitavelmente altera não apenas o sentido literal, mas 
também certas nuances, associações e o próprio significado cultural do material traduzido". Observa-se, neste caso, que não se trata de um caso de simples transcodificação, mas da eliminação de um diagrama que dava forma imagética à comparação, explicada verbalmente por Freire, entre a Teoria da Ação Revolucionária e a Teoria da Ação Opressora, que intensificava o sentido proposto para tais concepções.

Considerando-se a oralidade, aspecto difícil de ser transcodificado, como uma das marcas da idiossincrasia mais recorrente e perceptível da linguagem de Paulo Freire, não só na Pedagogia do Oprimido, como em todas as demais obras, entende-se que ela seja utilizada não como recurso estilístico, mas como marca de coerência discursiva e conceitual com o seu ideário, representando um movimento de aproximação da linguagem dos contextos populares para que a palavra pudesse colorir-se com os tons da realidade do oprimido. Assim, pode-se imaginar a difícil tarefa dos tradutores, não só para o inglês e para o espanhol (em 1970), como também para os mais de vinte e cinco idiomas para os quais a obra foi traduzida ao longo dos anos, para transcodificar culturalmente os neologismos, as criativas estruturas frasais e as produtivas metáforas tão presentes na linguagem freiriana. Assim, vale ressaltar a importância da descoberta e da publicação da versão manuscrita dessa obra seminal, para que ela possa ser considerada em futuras edições e traduções.

\section{A gênese da pedagogia do oprimido: um diálogo com a pedagogia da esperança}

Como argutamente afirma Leonardo Boff (2015, p. 12), no prefácio da $17^{\mathrm{a}}$ edição de Pedagogia da Esperança: um reencontro com a Pedagogia do Oprimido, publicado em 1992, as duas obras “[...] perfazem um livro só, aberto e em processo de contínua construção a partir dos próprios oprimidos e, por isso, sempre inacabado". Nessa incompletude talvez residam a atualidade e o interesse que a Pedagogia do Oprimido exerça até hoje sobre o leitor do século XXI. Enquanto perambularem pelas esquinas das ruas os condenados da terra de Frantz Fanon e os oprimidos de Paulo Freire, para designar todo e qualquer interditado social que, de alguma forma, seja estigmatizado e marcado pelos traços da discriminação e da opressão em quaisquer temposespaços, a obra permanecerá atual e terá ressonância mundial, já que todas as formas de exploração são idênticas, porque se aplicam todas por igual ao ser humano.

Pedagogia da Esperança pode ser entendida como uma reescritura palimpséstica ${ }^{3}$ de Pedagogia do Oprimido que permite ao leitor, pela voz do próprio Paulo Freire, conhecer a gênese do seu livro seminal, por meio da qual ele recorda, reafirma, explicita, autocritica-se, responde às críticas, ressignifica e descreve as tramas históricas que deram origem a sua obra mais importante.

\footnotetext{
${ }^{3} \mathrm{O}$ tema foi profundamente desenvolvido por Spigolon (2016).
} 
Com uma arquitetura composicional sem divisão em capítulos e assumindo-se como um narrador agradável de ser ouvido, nesse reencontro ele se debruça sobre as experiências que viveu e delas extrai suas considerações teóricas, em permanente estado de dialogação com as teorias, com as pessoas entre si, com a realidade que o envolveu no processo de criação da obra. Há de se concordar com a lúcida apreciação de Leonardo Boff (2015, p. 9), quando assevera que Pedagogia do Oprimido é "[...] mais que um livro, é antes uma prática pedagógica que, num momento de seu processo de constituição, ganhou corpo numa escritura”.

Em Pedagogia da Esperança, esse processo dialógico se repete e o pensador pernambucano reitera o procedimento, que é tanto ontológico quanto epistemológico, descrevendo minuciosamente o caminho que percorreu para escrever Pedagogia do Oprimido no exílio, entre 1967 e 1968. Esclarece que a obra foi tomando forma primeiro na oralidade e depois graficamente. Enquanto escrevia, ia discutindo os textos com os amigos com quem trabalhava, Marcelo Gajardo e José Luís Fiori:

[...] as horas que passávamos juntos, discutindo achados e não apenas meus textos, debatendo dúvidas, interrogando-nos, desafiando-nos, sugerindo-nos leituras, surpreendendo-nos, espantando-nos, exerciam em nós um tal encanto que, quase sempre, nossa fala, a partir de certa hora, era a única a ser ouvida no prédio (FREIRE, 2015, p. 73).

Depreende-se que o processo de criação/recriação da escrita de Paulo Freire reafirma a categoria mais importante do seu pensamento: a dialogicidade. Era preciso falar das ideias antes de enclausurá-las nos limites do papel, por isso ele incorporava as dúvidas ou afirmações dos camponeses que entrevistava nos círculos de cultura, dos técnicos agrícolas, dos educadores que encontrava nos seminários ou conferências, ou dos amigos com quem conversava, como forma de testá-las, de recriá-las, de partejá-las. Paulo Freire confessa ter levado mais de um ano nesse processo “[...] como se estivesse, e na verdade estava, aprendendo a escrevê-lo" (FREIRE, 2015, p. 75).

Em um poético fragmento da Pedagogia da Esperança, o leitor pode acompanhar o movimento artesanal que registra o momento da gestação de Pedagogia do Oprimido. Depois da fase de dialogação, uma nova etapa se iniciava: a do registro em fichas de ideias que eram anotadas em blocos, à medida que iam surgindo, organizadas em ordem crescente e identificadas com títulos, de acordo com o tema. Aos poucos, cada uma das fichas era ampliada em duas ou mais páginas e se convertia em ficha geradora de outras ideias. A redação da obra teve início em julho de 1967, quando foram escritos os três primeiros capítulos, datilografados e entregues ao amigo Ernani Maria Fiori, que o prefaciou e o devolveu em dezembro. "Quando Fiori me entregou seu excelente 
estudo em dezembro de 1967, tomei algumas horas em casa à noite, lendo o seu prefácio até a última palavra do terceiro capítulo, para mim, então, o último" (FREIRE, 2015, p. 83).

Após essa fase da escritura, o texto foi colocado em quarentena por dois meses. Ao relêlo, Freire percebeu que a obra estava inacabada e escreveu o quarto capítulo, depois de retocar os três primeiros: "(Naquele momento, mal poderia imaginar que 24 anos depois teria vários reencontros não mais com os originais, mas com o livro mesmo, para repensá-lo, para redizê-lo)" (FREIRE, 2015, p. 84).

Acrescentaríamos nós que ele mal poderia imaginar também que, quase 50 anos depois, seus leitores e seus admiradores do século XXI veriam concretizado seu antigo sonho de rever, transformado em uma nova obra, o manuscrito que testemunhou esse período de gestação.

Concluída a obra, o texto todo foi datilografado e, em seguida, ele reproduziu várias cópias que foram distribuídas aos amigos, entre os quais o casal Chonchol. A primeira edição brasileira só se concretizou em 1975, quando a obra já havia sido traduzida para o inglês, espanhol, italiano, francês e alemão.

Há controvérsias sobre qual teria sido a fonte das publicações brasileiras de Pedagogia do Oprimido. Alguns estudiosos do autor defendem que a procedência se deva à tradução do inglês, primeiro idioma em que a obra foi editada em 1970; outros pesquisadores defendem que teria sido o material enviado clandestinamente a Fernando Gasparian - diretor da editora Paz e Terra - pelas mãos de Jean Zigler, professor e intelectual suíço que, por motivos acadêmicos, viria ao Rio de Janeiro, em 1971, e ofereceu-se para trazer pessoalmente os originais. Mais uma vez é a saudosa voz de Paulo Freire que ressoa em Pedagogia da Esperança, reverberando em sua escritura a memória dos fatos vividos para que a história possa ser refletida.

\footnotetext{
Mesmo sabendo que o livro não poderia ser editado aqui; ter sua primeira edição em português, língua em que foi originalmente escrito, seria interessante que o texto datilografado chegasse às mãos de Fernando Gasparian, diretor da Paz e Terra, que o publicaria. A questão que se colocava era como remetê-lo com segurança, não só para os originais, mas também, e, sobretudo, para o portador. Àquela altura começos dos anos 1970, já morávamos em Genebra. Comentando o fato com intelectuais suíços, professores da Universidade de Genebra, um deles, além de professor, 'conseilleur national', professor Jean Zigler, me fez o oferecimento para trazer pessoalmente os originais. Ele viria ao Rio de Janeiro com tarefas acadêmicas. Aceitei seu oferecimento fundado em que, com seu passaporte diplomático, além de ser suíço, nada lhe ocorreria [...]. Dias depois, Gasparian, discretamente acusava o recebimento do material pedindo que esperasse por tempos mais favoráveis para a sua publicação. Remeti o texto nos fins de 1970, quando o livro já tinha sua primeira edição em inglês, ou nos começos de 1971. Sua publicação aqui, sua primeira impressão, só foi possível em 1975. Enquanto isso um sem número de brasileiras e brasileiros o liam em edições estrangeiras que chegavam aqui por golpes de astúcia e coragem (FREIRE, 2015, p. 8687).
}

Com a edição americana de 1970, por Werner Linz, a obra se espalhou rapidamente pelos quatro cantos do mundo, sobretudo a partir de sua publicação em Londres pela Penguim Books 
que, segundo o autor, “[...] estendeu a Pedagogia à África, à Ásia e à Oceania” (FREIRE, 2015, p. 167), gerando curiosidade, críticas favoráveis e desfavoráveis, aceitação e recusa, dependendo do lugar que ocupasse o leitor no cenário das tramas históricas, geográficas, sociais, culturais, políticas e ideológicas em que era lida.

Vale ressaltar, ainda, neste caminho que descreve a gestação da Pedagogia do Oprimido, a inegável contribuição de Elza Freire, que não só colaborou com a sistematização da teoria epistemológica e ontológica de Paulo Freire, como também foi a primeira leitora crítica da obra, enquanto ela ia sendo redigida:

De manhã, muito cedo, lia as páginas que eu escrevia até a madrugada e deixara arrumadas sobre a mesa. Às vezes, não se continha. Me acordava e, com humor, me dizia: "Espero que este livro não nos torne mais vulneráveis a novos exílios". (FREIRE, 2015, p. 90).

Justo reconhecimento póstumo que é feito a Elza Freire, o que corrobora a "boniteza" da relação que a história de ambos registra e valida a importância do seu papel enquanto agente ativa na gestação de Pedagogia do Oprimido.

Dessa forma, reler a versão manuscrita de uma obra canônica como Pedagogia do Oprimido, conhecendo o contexto histórico e o processo criativo que subjaz à obra, provê, de certa forma, seu renascimento e abre caminho para um novo reencontro, agora o do autor com seu leitor. Valida-se, assim, nossa hipótese inicial que vê a dialogicidade como o eixo vertebrador do pensamento, da prática e do movimento da escrita de Paulo Freire. Ela está presente, inclusive, nas marcas autorais do processo de criação de suas obras, que sempre dialogam entre si em um processo de recriação que produz significâncias sem fim. Na construção polifônica que marca a Pedagogia do Oprimido, muitas vozes são orquestradas, vozes exteriores e interiores que são sempre mobilizadas para produzir encontros e reencontros.

\section{Do manuscrito à obra editada}

Comparando-se a publicação fac-similada do manuscrito da obra Pedagogia do Oprimido, de 2013, com as versões impressas ao longo das sessenta edições da obra no Brasil até 2016, torna-se possível inferir que os tempos da escrita dialogam com os tempos da história e abrem novas possibilidades para o leitor do século XXI, tanto para apropriação de novos sentidos para a obra como também para a validação histórica do papel de Freire no cenário da educação.

Os editores dessa versão fac-similada ofereceram às sucessivas gerações de leitores de Paulo Freire uma nova obra, que impõe um outro pacto de leitura. Esse manuscrito adquiriu status de um 
novo livro, a partir do qual se torna possível estabelecer novas relações de significância para aqueles que já leram alguma das suas versões publicadas e/ou estão familiarizados com as categorias do pensamento freiriano.

Para essa direção aponta o estudo de Roger Chartier (2014), um dos estudiosos mais importantes que se debruça sobre a história do livro e da leitura. Na obra $A$ mão do autor e a mente do editor, o pesquisador francês faz uma verdadeira arqueologia do processo editorial das obras de Cervantes e Shakespeare, mostrando o caminho que percorre um livro a partir de sua gênese conduzida pela mão do autor até sua versão impressa mediada pela mente do editor, tentando identificar indícios dessas camadas textuais do material original até a versão definitiva.

Para o autor, a materialidade do livro é inseparável da materialidade do texto, isto é, tornase inseparável da forma como o texto se inscreve na página: “A mesma obra não é de fato a mesma quando muda sua linguagem, seu texto ou sua pontuação" (CHARTIER, 2014, p. 11).

Sem se deixar seduzir pelos juízos apocalípticos que apregoam a morte dos livros pelo avanço do mundo digital, Chartier se apoia na História para defender a coexistência de diferentes modalidades da palavra escrita - manuscrita, impressa e eletrônica -, mostrando que o significado do texto depende das formas que o tornam possível de ler, isto é, das diferentes características da materialidade da escrita, como o formato do livro, a letra, o layout da página, a forma como o texto está dividido, as concepções tipográficas e a pontuação. Assim, as formas materiais da palavra escrita marcam sempre os limites da recepção da obra; vale dizer, determinam como o leitor conduz seu movimento interpretativo. Desta forma, o leitor de 2013, ao ler o manuscrito de Pedagogia do Oprimido, em contato com essa materialidade da escritura, terá uma disposição sensível diferenciada para interpretá-la.

Trata-se de uma abordagem extremamente produtiva nos dias de hoje, a que propõe Chartier (2014), uma época em que as práticas da escrita têm sido profundamente modificadas, já que a revolução digital introduziu uma revisão radical dos gestos e dos conceitos que podem ser associados à palavra escrita. Ler, por meio de uma tela, conduz a uma leitura dispersa, segmentada, ligada aos fragmentos, mais do que à totalidade da obra, sem exibir os limites e a coerência do corpus do qual foram extraídos. Por essa razão, os textos se tornaram móveis, abertos e maleáveis, gerando outros movimentos de leitura. Da mesma forma, ler a edição manuscrita da obra (quer a impressa, quer a disponível na internet) exige do leitor habilidades diferentes para a construção do sentido da obra.

Chartier (2014) defende que os livros, sejam eles manuscritos ou impressos, sempre são resultantes de múltiplas operações que supõem uma variedade de decisões, técnicas e habilidades. 
São as formas materiais da palavra escrita e o repertório cultural dos seus leitores que marcarão sempre os limites da compreensão. Ele mostra que a recente conexão entre disciplinas, como crítica genética, história do livro e sociologia cultural, permite aprofundar a compreensão de como as apropriações dos leitores “[...] dependem de uma combinação dos efeitos de significados buscados pelos textos, usos, sentidos impostos pelas formas de publicação e competências e expectativas que governam a relação de cada comunidade interpretativa com a cultura escrita" (CHARTIER, 2014, p. 47).

$\mathrm{Na}$ esteira dessas reflexões, consideramos que, embora as edições impressas de Pedagogia do Oprimido apresentem estruturas básicas semelhantes às da edição manuscrita, trata-se de uma outra obra, pois se alteram suas condições de circulação e recepção, instaurando uma nova disposição sensível para sua leitura e adesão. Se cada uma dessas obras é única em sua essência imaterial, elas são múltiplas em suas organizações materiais.

Nessa direção, Chartier, apoiando-se na proposta de Gerard Genette (2006), ressalta a importância dos paratextos como vestíbulos, como zonas de transição e também de transação que influenciam e verticalizam a leitura que se faz de uma obra.

Afirma, ainda, que os meios e os modos da apresentação de um paratexto mudam continuamente, dependendo do período, da cultura, do gênero, do autor, da obra e da edição, exercendo diferentes graus de pressão sobre a obra. Genette (2006) distingue duas classes de elementos paratextuais: o peritexto que é encontrado dentro do próprio livro (título, epígrafe, prefácio, prólogo do autor, comentários preliminares, notas, ilustrações etc.) e o epitexto, que se situa fora do livro em si (envolvendo correspondência, diários, entrevistas etc.). Cada um desses elementos possui sua própria história e estão unidos por relações entre gêneros múltiplos. Como existem fortes elos entre esses elementos peritextuais e epitextuais, é preciso restaurar a lógica que os une: histórica e performativamente. A interpretação de cada um dos paratextos de uma obra é estreitamente dependente de todos os outros e interfere na leitura da obra. Pode-se deduzir, assim, que o manuscrito e suas versões derivadas podem ser considerados "encarnações históricas" diferentes da obra seminal de Paulo Freire, apresentando elementos paratextuais que os diferenciam e produzem efeitos diversos no leitor.

O fac-simile de Pedagogia do Oprimido pode ser descrito como a foto de um manuscrito original plasmada em um filme e reproduzida no papel. A partir de sua leitura, não é possível distinguir, por exemplo, a tinta utilizada no original e todos os fólios apresentam a dimensão da foto ampliada e a mesma coloração em preto e branco. Nesse cenário, o leitor se desloca para outro tempo-espaço e algo dessa experiência o transporta para sua gênese, evidenciando que essa forma textual 
manuscrita é irredutivelmente singular. É a marca autoral que corporifica Paulo Freire no material que está sendo lido, considerando-se que o ponto mais próximo a que um leitor pode chegar materialmente de uma obra é o traço deixado por quem a escreveu. Para Chartier (2014), o manuscrito assinado assume, assim, o signo exterior e visível do escritor para todos aqueles que não puderam conhecê-lo. Também as condições de circulação da obra foi ampliada, já que, além da versão impressa do fac-símile, o manuscrito foi digitalizado e democraticamente disponibilizado na internet para pesquisadores de qualquer parte do mundo. Mente e mão, presente e passado, história e tecnologia, palimpsesto e hipertexto caminhando juntos para perenizar a obra de um dos educadores mais importantes do século XX.

Por essas razões, não se pode prescindir da análise dos importantes elementos paratextuais que esse manuscrito apresenta, tanto sob a forma de epitextos (ou seja, a apresentação escrita pelos responsáveis pelo projeto editorial, a entrevista com Jacques Chonchol e a carta-dedicatória escrita por Paulo Freire, quando, em 1968, presenteou, com o manuscrito original da obra, os amigos chilenos Jacques Chonchol e sua esposa Maria Edy, a capa e sobrecapa e as orelhas), quanto sob a forma de peritextos internos à obra (título, epígrafe, sumário e prólogo do autor).

O advérbio, performativamente, está sendo usado neste contexto para indicar que os elementos paratextuais não só dizem (modus dicendi) como também mostram (modus mostrandi) e têm a propriedade de fazer (modus faciendi); isto é, realizam o ato que denotam. A esse respeito, remetemos à teoria de Austin (1970), Quand dire c'est faire.

Com Chartier (2014), assumimos a defesa da importância de que todos os estados do texto devem ser analisados de forma global, já que são resultantes de atos de escrita de práticas gráficas diferentes, tendo-se claro que o objetivo não é buscar intenções do autor ou revelar um texto ideal, mas explicitar o que foi alterado de um estado da obra para o outro, descrevendo-se as escolhas feitas, como rasuras, divisões, pontuações ou características de seus paratextos.

Com essa análise, ele aplaca a oposição existente entre duas posições antagônicas: aquela que afirma que a obra transcende todas as suas possíveis encarnações materiais e a que defende que não há texto externo aos seus aspectos materiais. O autor relativiza as duas, argumentando que estabelecer uma oposição frontal entre essas duas concepções é dar início a uma falsa contenda. $\mathrm{Na}$ verdade, o historiador francês defende que as obras, em suas sucessivas edições, sempre têm sido apresentadas, para a leitura, em formas particulares. De acordo com a época em que são apresentadas e com o gênero a que pertencem, elas carregam variações referentes à materialidade da obra, à grafia das palavras ou à composição do texto em si. Por outro lado, também é verdade que, do ponto de vista filosófico, jurídico e estético, sempre houve a tentativa de reduzir essa 
diversidade, postulando a existência de uma obra idêntica a si mesma, qualquer que pudesse ser a sua forma (manuscrita ou editada).

Para além dessas posições extremadas, ponderamos que o realmente importante é registrar como a obra foi gestada e materializada em cada momento da sua história, sob a forma do manuscrito, do livro impresso, das suas reedições ou da mídia digital.

Contextualizando essas proposições gerais de Roger Chartier, valemo-nos de Gadotti (2016), que elucida importantes aspectos históricos das sucessivas edições de Pedagogia do Oprimido, testemunhando que

\footnotetext{
As primeiras edições do livro não eram inteiramente fiéis aos originais. Paulo Freire sabia disso. Por isso, numa dedicatória a Moacir Gadotti, da $17^{a}$ edição (1987), Paulo Freire afirma que era a "primeira edição decente" do livro. Mesmo assim, como Paulo Freire (GADOTTI, 2016, p. 6).
}

Em uma esclarecedora nota, Gadotti recorda o contexto em que o próprio Paulo Freire fez a revisão crítica de sua obra e lhe entregou um exemplar da $17^{a}$ edição com os seguintes termos: "Para Rê (Rejane, esposa de Gadotti) e Moacir, esta primeira edição decente da Pedagogia em português. Abração. Paulo. Abril de 81” (GADOTTI, 2016, p. 6).

Gadotti esclarece que, ao preparar essa nova edição, classificada por Freire como "decente", observa-se a meticulosa releitura que foi feita da obra por diversas glosas (oumarginálias, como preferem os geneticistas). Nessa acurada revisão, o educador pernambucano

\footnotetext{
Põe várias interrogações na $15^{\mathrm{a}}$ edição do livro onde estão essas anotações. São raras as páginas em que não existe nenhum comentário ou anotação. Na página 171, por exemplo, ele escreve ao lado do primeiro parágrafo: "truncado"; na página 213 ele escreve: "frase de significação dúbia". depois desta leitura atenta ele preparou a nova edição. (GADOT'TI, 2016, p. 6).
}

Assim, novamente, vemos confirmada nossa hipótese de que a categoria da dialogicidade freiriana é tão visceral que dela não escapa sequer a relação que ele estabelece com a sua própria escritura. Como se sabia inacabado, é provável que novas contextualizações, revisões e reedições de Pedagogia do Oprimido brindariam os leitores e admiradores do saudoso educador no século XXI, se vivo ele estivesse.

Dessa forma, o manuscrito da Pedagogia do Oprimido, como diz o próprio Chartier (2014) em seu prefácio, possibilita “[...] escuchar a los muertos com los ojos" e ressignificar antigos sentidos

${ }^{4}$ Tradução do espanhol: "Escutar os mortos com os olhos". 
para palavras silenciadas nesse texto em que o vestígio dos escritos nele inseridos foi preservado e ainda possibilita que deles seus leitores possam extrair novas ressonâncias.

\section{Considerações finais}

Revisitar o itinerário do contexto histórico que a Pedagogia do Oprimido percorreu enquanto obra datada, que completou em 2018 cinquenta anos, desde sua versão manuscrita até as edições atuais, reafirmou nossa convicção de que a dialogicidade é vetor que perpassa todas as categorias freirianas e alicerça seu ethos político-pedagógico, desvelado por uma maneira personalíssima de dizer sua palavra, de se mostrar no texto e de agir no discurso e no mundo.

Esse constructo-matriz se manifesta mais intensamente ainda diante do manuscrito da obra "ex auctoritate propria", vale dizer, pela autoridade do próprio exemplo que Freire revela pela interação com o seu texto, já que foi esse o princípio sobre o qual ele construiu suas proposições ontológicas, epistemológicas, metodológicas, exercitando-o também em sua prática textual e discursiva. Esse aspecto ganha maior visibilidade quando o leitor se depara com o manuscrito e dele tenta extrair novas ressonâncias de sentidos, que estão impregnadas nas rasuras ali presentes.

Essa dialogicidade estrutural coloca em situação de diálogo suas próprias obras, como ocorre em Pedagogia da Esperança: um reencontro com a Pedagogia do Oprimido, que possibilita que o leitor se depare com um verdadeiro espaço biográfico em que Paulo Freire descreve detalhadamente o cenário que viu nascer, em 1968, sua obra seminal, recuperando valores vivenciais significativos e simbólicos dessa topografia.

Sua obra é sempre inacabada, como é o ser humano que, em sua incompletude, necessita de reelaboração constante. Consciente desse inacabamento, Freire vai tecendo os fios do seu próprio discurso, ressignificando seus constructos em novos contextos e liberando sempre um potencial sentido oculto que o obriga a revisões e releituras permanentes.

Em contato com o manuscrito, que veio a público em 2013, o leitor é transportado para outra dimensão espaço-temporal e constrói metonimicamente em sua imaginação uma corporalidade, pela mão que se materializa no padrão caligráfico e nas rasuras que dão suporte à obra.

Assim, Pedagogia do Oprimido: (o manuscrito) se torna uma nova obra, se comparada às inúmeras versões editadas, afetando diferentemente o leitor de hoje, já que as suas condições de produção e de recepção foram alteradas por uma cenografia, atribuindo um novo status a ela e elevando-a à condição de documento histórico, social e discursivo inédito, sendo um importante instrumento de preservação de sua memória. Concluindo, vive-se hoje uma época em que mais do 
que nunca se torna imprescindível reavivar o pensamento freiriano e fazer reviver a sua voz. A leitura do manuscrito talvez possa conclamar leitores a fazer ou refazer uma leitura de sua palavra para revivê-la, rejeitando toda forma de banalização do seu pensamento, que impeça uma leitura diminuidora da profundidade e do alcance de suas ideias.

\section{Referências}

AUSTIN, John L. Quand dire c'est faire. Paris: Seuil, 1970.

BAKHTIN, Mikhail. Marxismo e filosofia da linguagem: problemas fundamentais do método sociológico na ciência da linguagem. Tradução de Michel Lahud e Yara Frateschi Vieira. 8. ed. São Paulo: Hucitec, 1997.

BARTHES, Roland. O rumor da lingua. Lisboa: Editora 70, 1987.

BENJAMIN, Walter. Magia e técnica, arte e política: ensaios sobre literatura e história da cultura. Tradução de Sérgio Paulo Rouanet. 7. ed. São Paulo: Brasiliense, 1994. (Obras Escolhidas, v. 1).

BOFF, Leonardo. Prefácio. In: FREIRE, Paulo. Pedagogia da Esperança: um reencontro com a Pedagogia do Oprimido. São Paulo: Paz e Terra, 2015. p. 9-12.

CHARTIER, Roger. A mão do autor e a mente do editor. Tradução de George Schlesinger. São Paulo: Editora Unesp, 2014.

CHONCHOL, Jacques. Entrevista concedida a José Eustáquio Romão. In: FREIRE, Paulo. Pedagogia do Oprimido: (o manuscrito). Projeto editorial, organização, revisão e textos introdutórios de Jason Ferreira Mafra, José Eustáquio Romão e Moacir Gadotti. São Paulo: Editora e Livraria Instituto Paulo Freire, 2013. p. 6-10.

FREIRE, Paulo. Pedagogia do Oprimido: (o manuscrito). Projeto editorial, organização, revisão e textos introdutórios de Jason Ferreira Mafra, José Eustáquio Romão e Moacir Gadotti. São Paulo: Editora e Livraria Instituto Paulo Freire, 2013.

FREIRE, Paulo. Pedagogia da Esperança: um reencontro com a Pedagogia do Oprimido. 22. ed. Rio de Janeiro: Paz e Terra, 2015.

GADOTTI, Moacir. Alfabetizar e conscientizar: Paulo Freire, 50 anos de Angicos. São Paulo: Editora e Livraria Instituto Paulo Freire, 2014.

GADOTTI, Moacir. Pedagogia do Oprimido: Leitura de seus leitores e intérpretes. 2016. Disponível em: http://gadotti.org.br:8080/jspui/handle/123456789/427. Acesso em: 27 mar. 2017.

HUTCHEON, Linda. Uma teoria da adaptação. Tradução de André Cechinel. Florianópolis: Ed. da UFSC, 2011.

MAFRA, Jason F.; ROMÃO, José E.; GADOTTI, Moacir. Apresentação. In: FREIRE, Paulo. Pedagogia do Oprimido: (o manuscrito). Projeto editorial, organização, revisão e textos introdutórios 
de Jason Ferreira Mafra, José Eustáquio Romão e Moacir Gadotti. São Paulo: Editora e Livraria Instituto Paulo Freire, 2013. p. 4-5.

ROMÃO, José E. Brasil nunca aplicou Paulo Freire. [Entrevista cedida a] Camilla Campos. BBC Brasil, 24 jul. 2015. Disponível em:

https://www.bbc.com/portuguese/noticias/2015/07/150719_entrevista_romao_paulofreire_cc. Acesso em: 20 jan. 2016.

SPIGOLON, Nima I. Pedagogia da convivência: Elza Freire - uma vida que faz educação. Jundiaí: Paco Editorial, 2016. 